\title{
Effects of IL-1ß on the proliferation and apoptosis of gastric epithelial cells and acid secretion from isolated rabbit parietal cells
}

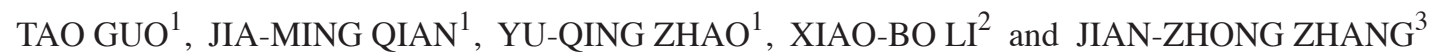 \\ ${ }^{1}$ Department of Gastroenterology, Peking Union Medical College Hospital, Chinese Academy of Medical Sciences, \\ Beijing 100730; ${ }^{2}$ Institute of Hepatology, People's Hospital, Beijing University, Beijing 100044; \\ ${ }^{3}$ Department of Diagnosis, Institute for Communicable Disease Control and Prevention, \\ Chinese Center for Disease Control and Prevention, Beijing 102206, P.R. China
}

Received June 2, 2012; Accepted October 9, 2012

DOI: $10.3892 / \mathrm{mmr} .2012 .1165$

\begin{abstract}
The aim of the present study was to explore the effects of IL-1 $\beta$ on the proliferation and apoptosis of gastric epithelial cells and acid secretion from isolated rabbit parietal cells. The mechanisms by which these effects are mediated were also investigated. Parietal cells were isolated from rabbit gastric mucosa by elutriation. The AGS human gastric cancer cell line, the GES-1 human gastric epithelial cell line and parietal cells were treated with interleukin (IL)-1 $\beta$ in the presence or absence of Helicobacter pylori (H. pylori) for the times indicated. MTT assay and flow cytometry (FCM) were used to determine the levels of proliferation and apoptosis. The expression levels of cyclooxygenase-2 (COX-2) mRNA and protein were examined by RT-PCR and FCM. Acid secretion by parietal cells was examined using ${ }^{14} \mathrm{C}$-aminopyrine $\left({ }^{14} \mathrm{C}\right.$-AP) accumulation. $\mathrm{H}^{+} / \mathrm{K}^{+}$ATPase $\alpha$ subunit mRNA expression was assessed by RT-PCR. The results demonstrated that IL-1 $\beta(10 \mathrm{ng} / \mathrm{ml})$ stimulated cellular proliferation and inhibited $H$. pylori-induced apoptosis in GES-1 and AGS cell lines. IL-1 $\beta(10 \mathrm{ng} / \mathrm{ml})$ upregulated the mRNA and protein expression of COX-2 in GES-1 and AGS cells. Acid secretion stimulated by histamine was identified as significantly inhibited and mRNA expression of $\mathrm{H}^{+} / \mathrm{K}^{+}$ATPase $\alpha$ subunit was downregulated by treatment with IL-1 $\beta$ (10 ng/ml) for $30 \mathrm{~min}$ and $16 \mathrm{~h}$ compared with the control in isolated rabbit parietal cells. The present study demonstrates that IL-1 $\beta$ plays a significant role in $H$. pylori-induced gastric carcinogenesis through 2 main mechanisms: i) IL-1 $\beta$ may interfere in gastric epithelial cell growth by upregulating COX-2 expression; ii) IL-1 $\beta$ may
\end{abstract}

Correspondence to: Professor Jia-Ming Qian, Department of Gastroenterology, Peking Union Medical College Hospital, Chinese Academy of Medical Sciences, 1 Shuaifuyuan, Wanfujing, Beijing 100730, P.R. China

E-mail: qianjiaming5555@126.com

Key words: Helicobacter pylori, gastric cancer, interleukin-1, cyclooxygenase- $2, \mathrm{H}^{+} / \mathrm{K}^{+}$ATPase inhibit the acid secretion from parietal cells by downregulating $\mathrm{H}^{+} / \mathrm{K}^{+}$ATPase expression.

\section{Introduction}

Helicobacter pylori (H. pylori) infection is associated with divergent clinical outcomes that range from simple asymptomatic gastritis to more serious conditions, including peptic ulcer disease and gastric neoplasia (1). A number of previous studies have focused on the role of bacterial virulence factors in the pathogenesis of these diseases. Although these factors undoubtedly contribute to the degree of tissue damage, the 2 key outcomes, gastric cancer and duodenal ulcer disease, have yet to be distinguished (2). Therefore, understanding of host genetic factors that may be relevant to this process must be developed further.

The key pathophysiological event in $H$. pylori infection is initiation of a gastric mucosal inflammatory response, which is mediated and regulated by a large number of pro-inflammatory cytokines, particularly interleukin (IL)-1 $\beta$, IL-6 and IL-8 $(3,4)$. Previous studies have demonstrated that the host genetic polymorphisms of IL- $1 \beta$ are relevant to $H$. pylori-associated gastric cancer. Polymorphisms in the IL- $1 \beta$ gene that correlate with increased levels of the cytokine have been identified to increase the risk of hypochlorhydria and gastric atrophy in response to $H$. pylori infection, therefore increasing the risk of gastric cancer itself (5-7). To this end, IL-1 $\beta$, as a potent proinflammatory cytokine, may be involved in the host response to $H$. pylori infection. At present, the molecular mechanisms associated with the correlation between the risk of gastric cancer and the polymorphisms of IL-1 $\beta$ remain unclear.

Disturbance of the balance between proliferation and apoptosis of gastric epithelial cells is considered to interfere with the integrity of gastric mucosa and promote the development of gastric carcinogenesis $(8,9)$. Gastric acid hyposecretion also correlates with increased risk of gastric cancer (5). Therefore, in the present study, we investigated the effects of exogenous IL-1 $\beta$ on proliferation and apoptosis of gastric epithelial cells and acid secretion of isolated rabbit parietal cells in order to explore the role of IL-1 $\beta$ in $H$. pylori-associated diseases and 
to identify the mechanisms involved in $H$. pylori-induced gastric carcinogenesis.

\section{Materials and methods}

Gastric epithelial cell culture. The human gastric cancer cell line, AGS, and the human gastric epithelial cell line, GES-1, were maintained in RPMI-1640 medium containing 10\% FBS and in MCDB-153 medium supplemented with 10\% FBS, respectively, at $37^{\circ} \mathrm{C}$ with $5 \% \mathrm{CO}_{2}$ and $95 \%$ air in a humidified incubator. The 2 cell lines were preserved in our laboratory. Cells were serum-starved for $12 \mathrm{~h}$ prior to treatment and then treated with either vehicle or test reagents for the indicated time.

Parietal cell preparation. Rabbit parietal cells were isolated and enriched from male New Zealand rabbits $(2 \pm 0.2 \mathrm{~kg})$ using a modification of previously described methods (10). Briefly, gastric fundic mucosa was digested with sequential exposure to type I crude collagenase $(30-40 \mathrm{mg} / 100 \mathrm{ml}$; Sigma-Aldrich, St. Louis, MO, USA) and EDTA (1-2 mmol/1). Parietal cells were enriched from the crude suspension by the standard centrifugal elutriation technique using a Beckman JE6B elutriation system. For selected experiments, further purification of parietal cells was performed using continuous density gradient centrifugation with 50\% Percoll (Pharmacia, Piscataway, NJ, USA). Parietal cells were enriched to $>70 \%$ homogeneity as determined by hematoxylin and eosin staining and $>95 \%$ viability as determined by trypan blue exclusion.

Harvested cells from the parietal cell-enriched fractions were collected by brief centrifugation and resuspended in complete culture medium (Ham's F12/DMEM, 1:1). Cells were cultured at $37^{\circ} \mathrm{C}$ in $5 \% \mathrm{CO}_{2}, 95 \%$ air for $12 \mathrm{~h}$ prior to treatment and then treated with either vehicle or IL-1 $\beta$ (PeproTech, Rocky Hill, NJ, USA) for the indicated time.

H. pylori preparation. Cytotoxin-associated gene A (CagA)positive and cytotoxin-producing $H$. pylori (NCTC 11637) strain was used in the present study. Bacteria were grown under microaerophilic conditions on Columbia agar plates (supplemented with $8 \%$ sheep blood) for $72 \mathrm{~h}$, harvested and resuspended in RPMI-1640 medium. Bacterial concentrations were standardized by optical density measurement at $600 \mathrm{~nm}$ and validated by serial dilution. $\mathrm{OD}_{600}$ of $\sim 1.0$ corresponded to a bacterial concentration of $1.5 \times 10^{8} \mathrm{cfu} / \mathrm{ml}$.

MTT assay. Cell proliferation was analyzed using MTT assay. Cells were seeded on a 96-well plate at $1.0 \times 10^{4}$ and $0.5 \times 10^{4}$ cells/well for GES-1 and AGS cells, respectively and incubated with increasing concentrations of IL-1 $\beta(0.1,1.0$ and $10 \mathrm{ng} / \mathrm{ml}$ ) for $24 \mathrm{~h}$ in serum-free culture medium. Each sample had 6 replicates. MTT $(0.5 \mathrm{mg} / \mathrm{ml})$ was added and the reaction mixture was incubated for $4 \mathrm{~h}$ at $37^{\circ} \mathrm{C}$. Following MTT incubation, cells were lysed in $150 \mu \mathrm{l}$ of $10 \%$ DMSO and the absorbance at $490 \mathrm{~nm}$ was measured using an automatic plate reader (Bio-Rad, Hercules, CA, USA). Viable cell number was expressed as a percentage of control: MTT assay $(\%$ control $)=\mathrm{OD}_{\text {test }} / \mathrm{OD}_{\text {control }}$.

Assessment of cell apoptosis. AGS and GES-1 cells were treated with either vehicle or test reagents for $24 \mathrm{~h}$ prior to assessment of apoptosis. Cells floating in the culture medium were collected by centrifugation and adherent cells were harvested by incubation with $1 \%$ trypsin for $1-2$ min at $70-80 \%$ confluence. Following washing with ice-cold PBS, cells were suspended in $70 \%$ ethanol and kept at $4^{\circ} \mathrm{C}$ for $30 \mathrm{~min}$. Fixation was terminated by washing twice with $\mathrm{PBS}$ and the cells were stained with propidium iodide $(100 \mu \mathrm{g} / \mathrm{ml})$ at $4^{\circ} \mathrm{C}$ for $30 \mathrm{~min}$. The cell suspension was filtered through $50-\mu$ m nylon mesh and DNA fluorescence was analyzed by flow cytometry (FCM; Beckman Coulter, Miami, FL, USA). A minimum of 10,000 events were measured per sample. Apoptosis was detected by the appearance of a sub-G1 fraction of fragmented nuclei in the analysis. Apoptosis was expressed as a percentage of the control and caluculated as: apoptotic cell $(\%)_{\text {test }}$ /apoptotic cell $(\%)_{\text {control }}$.

Detection of $m R N A$ by $R T-P C R$. Using a RNA extraction kit according to the manufacturer's instructions, total cellular RNA was isolated from AGS/GES-1 and parietal cells, which were treated with vehicle or IL-1 $\beta(10 \mathrm{ng} / \mathrm{ml})$ for indicated times prior to isolation. RNA $(2 \mu \mathrm{g})$ from each sample was reverse transcribed using Supercript II RT system (Invitrogen Life Technologies, Carlsbad, CA, USA) in a total reaction volume of $20 \mu \mathrm{l}$ and the resulting cDNA was amplified by PCR. The PCR primer sequences ( $F$, forward; $R$, reverse) and PCR product size were as follows: cyclooxygenase-2 (COX-2)-F, 5'-TTCAAATGAGATTGTGGGAAAATTGCT-3' and COX-2-R, 5'-AGATCATCTCTGCCTGAGTATCTT-3', 305 bp; $\beta$-actin-F, 5'-CCAGAGCAAGAGAGGTATCC-3', $\beta$-actin-R, 5' - CTGTGGTGGTGAAGCTGTAG-3', 463 bp; $\mathrm{H}^{+} / \mathrm{K}^{+}$ATPase $\alpha$ subunit-F, 5'-ACTCTGGGCTCCACGTCG-3', $\mathrm{H}^{+} / \mathrm{K}^{+}$ATPase $\alpha$ subunit-R,5'-AGGATGGAGCTGCAGCGC-3', 470 bp; UBCP-F, 5'-AGAAGAAGTCTTACACCACTC-3', UBCP-R, 5'-GTAAGTCAGACAACATTTGCC-3', 203 bp. For $\mathrm{COX}-2 / \beta$-actin, the PCR mixture was heated to $95^{\circ} \mathrm{C}$ for $5 \mathrm{~min}$ and amplification was performed for 35 cycles: denaturation at $95^{\circ} \mathrm{C}$ for $50 \mathrm{sec}$, annealing at $58^{\circ} \mathrm{C}$ for $60 \mathrm{sec}$ and extension at $72^{\circ} \mathrm{C}$ for $60 \mathrm{sec}$. Following the final cycle, the reactions were incubated at $72^{\circ} \mathrm{C}$ for an additional $10 \mathrm{~min}$. For $\mathrm{H}^{+} / \mathrm{K}^{+}$ATPase $\alpha$ subunit/UBCP, amplification was performed for 35 cycles: denaturation at $95^{\circ} \mathrm{C}$ for $60 \mathrm{sec}$, annealing at $62^{\circ} \mathrm{C}$ for $60 \mathrm{sec}$ and extension at $72^{\circ} \mathrm{C}$ for $60 \mathrm{sec}$. PCR products were electrophoretically separated on $1.5 \%$ agarose gels containing $0.5 \mu \mathrm{g} / \mathrm{ml}$ ethidium bromide and visualized under ultraviolet transillumination. Quantification of COX-2 and $\mathrm{H}^{+} / \mathrm{K}^{+}$ATPase ATPase $\alpha$ subunit PCR products were standardized in comparison with the housekeeping gene, $\beta$-actin, and UBCP products, respectively, by densitometry. The mRNA expression levels of the control group was expressed as $100 \%$. Levels of mRNA expression were presented as a percentage of the control.

Analysis of protein expression by FCM. Goat anti-COX-2 IgG antibody (Santa Cruz Biotechnology, Santa Cruz, CA, USA) was used as primary antibody and FITC-labeled rabbit anti-goat IgG antibody was used as secondary antibody for indirect immunofluorescence according to the manufacturer's instructions. Briefly, AGS and GES-1 cells, treated with the vehicle or IL-1 $\beta(10 \mathrm{ng} / \mathrm{ml})$ for the indicated times, were washed with PBS and fixed in $4 \%$ paraformaldehyde 
for $40 \mathrm{~min}$. Following fixation, cells were washed twice and treated with $0.2 \%$ Triton X-100 containing 5\% FBS on ice for $10 \mathrm{~min}$. Cells were washed again with PBS and then incubated with a 1:50 dilution of anti-COX-2 antibody at $4^{\circ} \mathrm{C}$. Following incubation for $40 \mathrm{~min}$, cells were washed twice, further incubated with a 1:100 dilution of the FITC-labeled secondary antibody at $4{ }^{\circ} \mathrm{C}$ for $40 \mathrm{~min}$, washed twice and filtrated through a 50- $\mu \mathrm{m}$ nylon mesh. Specific fluorescence was measured by FCM. For data acquisition, a gate was set on intact cells by forward/side scatter analysis and a minimum of 10,000 events were analyzed. Protein expression levels are presented as the mean fluorescence intensity (MFI) and expressed as the relative MFI following correction for non-specific fluorescence using the isotype control ( $\left.\mathrm{MFI}_{\mathrm{COX}-2} / \mathrm{MFI}_{\text {isotype control }}\right)$.

Measurement of acid secretion. Intracellular accumulation of ${ }^{14} \mathrm{C}$-aminopyrine $\left({ }^{14} \mathrm{C}\right.$-AP $)$ was used as an indirect measurement of functional acid secretory activity by parietal cells $(11,12)$. Cultured parietal cells, treated with vehicle or IL-1 $\beta(10 \mathrm{ng} / \mathrm{ml})$ for the indicated times, were washed with EBSS containing 0.2\% BSA, 2 mmol/1 glutamine, 20 mmol/1 HEPES ( $\mathrm{pH} 7.4$ ) to remove dead and non-adherent cells and resuspended in the medium described above at $1.0 \times 10^{6}$ cells $/ \mathrm{ml} .{ }^{14} \mathrm{C}-\mathrm{AP}(0.1 \mu \mathrm{Ci}$; GE Healthcare Biosciences, Pittsburgh, PA, USA) was added to $1.0 \mathrm{ml}$ of the cell suspension and the mixture was equilibrated at $37^{\circ} \mathrm{C}$ for $15 \mathrm{~min}$. Following thorough mixing of the cells, secretagogue histamine $\left(10^{-4} \mathrm{mmol} / \mathrm{l}\right.$; Sigma-Aldrich $)$ was added to stimulate the parietal cells to uptake ${ }^{14} \mathrm{C}$-AP and the cells were incubated at $37^{\circ} \mathrm{C}$ for $30 \mathrm{~min}$ in an atmosphere of $5 \% \mathrm{CO}_{2}$ and $95 \%$ air. Incubation was terminated by rapidly removing the medium by centrifugation and washing twice with EBSS solution. The cell pellet was lysed with $0.5 \mathrm{ml} 1 \%$ Triton $\mathrm{X}-100$. Aliquots of cell lysates were counted in a Beckman LS-6800 liquid scintillation counter with dinitrophenol (DNP) correction. DNP $(0.1 \mathrm{mmol} / \mathrm{l})$ was added separately to assess non-specific incorporation and values were subtracted from the test and control values. ${ }^{14} \mathrm{C}$-AP uptake was expressed as a percentage of control and calculated as: $\left({ }^{14} \mathrm{C}\right.$-AP uptake of IL-1 $\beta$ group $-{ }^{14} \mathrm{C}$-AP uptake of DNP group $) /\left({ }^{14} \mathrm{C}\right.$-AP uptake of control group $-{ }^{14} \mathrm{C}$-AP uptake of DNP group).

Statistical analysis. Values are expressed as the means \pm SD of at least 6 independent experiments. Six replicates were performed in each experiment. The Student's t-test, one-way ANOVA and Mann-Whitney U test were performed for statistical evaluation of the data using the SPSS 17.0 statistical software package. $\mathrm{P}<0.05$ was considered to indicate a statistically significant difference.

\section{Results}

Effect of increasing concentrations of IL-1 $\beta$ on cell proliferation in AGS and GES-1 cells. Cell proliferation was increased in AGS and GES- 1 cells by increasing the concentration of IL- $1 \beta$ $(0.1,1.0$ and $10 \mathrm{ng} / \mathrm{ml})$. A significant increase in the proliferation rate in response to IL-1 $\beta(10 \mathrm{ng} / \mathrm{ml})$ was identified compared with the control group in AGS and GES-1 cells ( $\mathrm{P}<0.05$; Fig. 1).

Effect of IL-1 $\beta$ on H. pylori-induced apoptosis in AGS and GES-1 cells. The apoptosis of AGS and GES-1 cells was

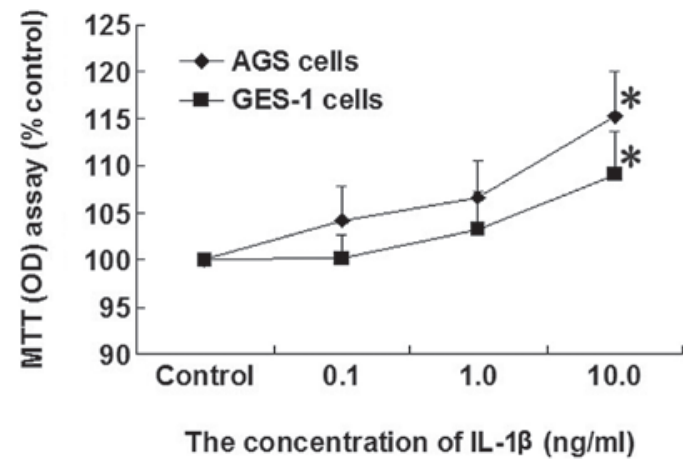

Figure 1. Effect of IL-1 $\beta$ on proliferation of AGS and GES-1. AGS and GES-1 cells were treated with various concentrations of IL-1 $\beta(0.1,1.0$ and $10 \mathrm{ng} / \mathrm{ml})$ for $24 \mathrm{~h}$. Level of proliferation was examined by MTT assay. Optical density of control group was expressed as $100 \%$. Results were expressed as a percentage of the basal control. All data are expressed as the means \pm SD $(n=6)$. ${ }^{*} \mathrm{P}<0.05$, compared with the control group.

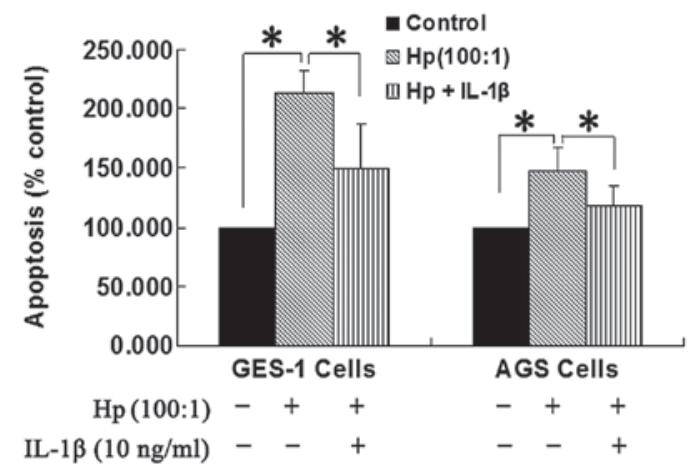

Figure 2. Inhibitory effects of IL-1 $\beta$ on $H$. pylori-induced apoptosis in AGS and GES-1 cells. AGS and GES-1 cells were exposed to H. pylori $(\mathrm{CFU} / \mathrm{cell}=100 / 1)$ with or without IL-1 $\beta(10 \mathrm{ng} / \mathrm{ml})$ for $24 \mathrm{~h}$. The level of apoptosis was examined by flow cytometry. The apoptotic rate of the control group was expressed as $100 \%$. Results are expressed as a percentage of the basal control. All data were expressed as the means $\pm \operatorname{SD}(n=6){ }^{*} \mathrm{P}<0.05$.

significantly increased in the $H$. pylori group compared with the control $(\mathrm{P}<0.05$; Fig. 2$)$. IL-1 $\beta(10 \mathrm{ng} / \mathrm{ml})$ exposure for $24 \mathrm{~h}$ significantly attenuated the $H$. pylori-induced apoptosis by 61.1 and $56 \%$ in the AGS cells and GES-1 cells, respectively, compared with the H. pylori group ( $\mathrm{P}<0.05$; Fig. 2).

Effect of IL-1 $\beta$ on expression of COX-2 mRNA in AGS and GES-1 cells. Compared with the control group, mRNA expression of COX-2 in the AGS cell line was significantly upregulated following treatment with IL-1 $\beta$ (10 ng/ml) for $8 \mathrm{~h}$ $(\mathrm{P}<0.05$; Fig. 3). A similar result was obtained in the GES-1 cell line $(\mathrm{P}<0.05)$.

Effect of IL-1 $\beta$ on expression of COX-2 protein in AGS and GES-1 cells. As demonstrated in Fig. 4, the protein expression of COX-2 was significantly increased following treatment with IL-1 $\beta(10 \mathrm{ng} / \mathrm{ml})$ for $8 \mathrm{~h}$ in the AGS and GES-1 cell lines compared with the control group (all $\mathrm{P}<0.05$ ). These results indicated that the effect of IL-1 $\beta$ on COX-2 protein expression was consistent with the effect on COX-2 mRNA expression. 
A
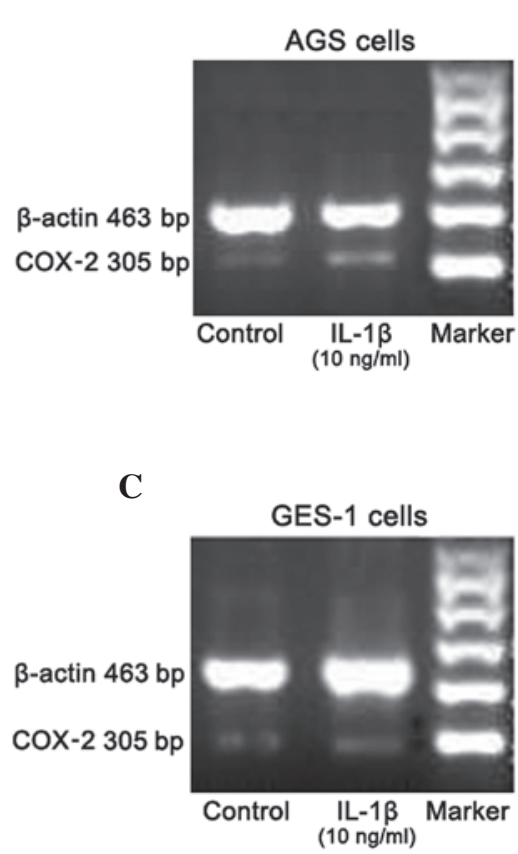

B

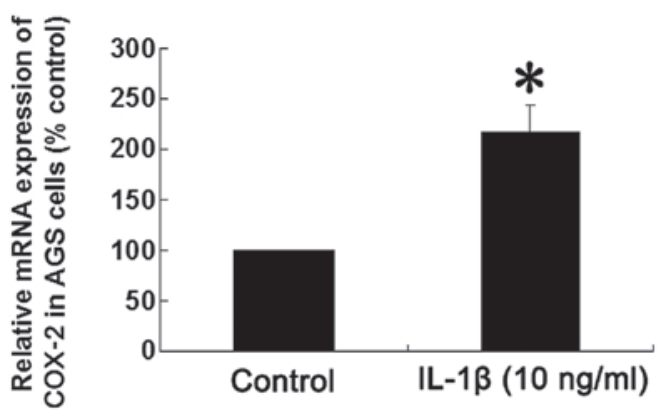

D
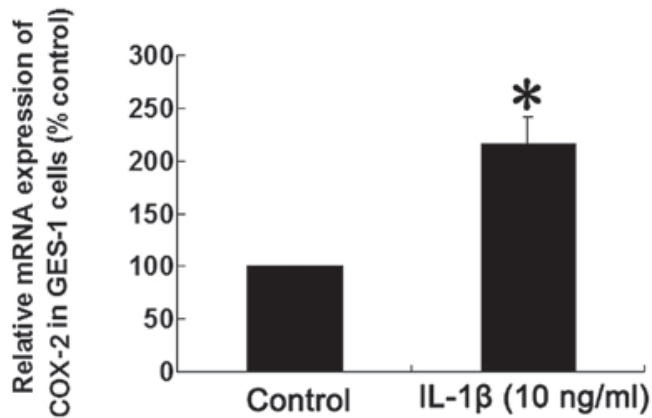

Figure 3. Effects of IL-1 $\beta$ on the expression of COX-2 mRNA in (A and B) AGS and (C and D) GES-1 cells. AGS and GES-1 cells were treated with IL-1 $\beta$ $(10 \mathrm{ng} / \mathrm{ml})$ for $8 \mathrm{~h}$. Level of mRNA expression was determined by RT-PCR and the mRNA expression of the control group was expressed as $100 \%$. Results are expressed as a percentage of the control. Data are expressed as the means $\pm \mathrm{SD}(\mathrm{n}=6)$. ${ }^{*} \mathrm{P}<0.05$, compared with the control group.

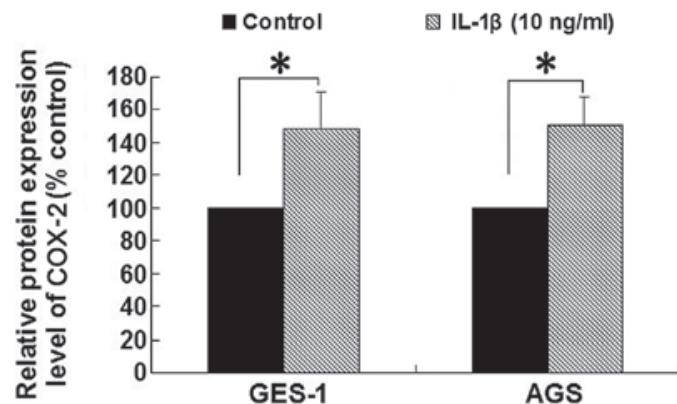

Figure 4. Effect of IL-1 $\beta$ on protein expression of COX-2 in AGS and GES-1 cells. AGS and GES-1 cells were treated with IL-1 $\beta(10 \mathrm{ng} / \mathrm{ml})$ for $8 \mathrm{~h}$. Level of protein expression was determined by flow cytometry. Protein expression of the control group is expressed as $100 \%$. Results are expressed as a percentage of the control. Data are presented as the means $\pm \mathrm{SD}(\mathrm{n}=6),{ }^{*} \mathrm{P}<0.05$.

Effect of IL-1 $\beta$ on acid secretion in isolated rabbit parietal cells. The acid secretion stimulated by histamine significantly inhibited by 14 and $50 \%$ following treatment with IL-1 $\beta$ $(10 \mathrm{ng} / \mathrm{ml})$ for $30 \mathrm{~min}$ and $16 \mathrm{~h}$, respectively, compared with the control group in isolated rabbit parietal cells (all $\mathrm{P}<0.05$; Fig. 5). Compared with the group treated with IL-1 $\beta(10 \mathrm{ng} / \mathrm{ml})$ for $30 \mathrm{~min}$, acid secretion stimulated by histamine was significantly decreased in the group treated with IL-1 $\beta(10 \mathrm{ng} / \mathrm{ml})$ for $16 \mathrm{~h}$. These results demonstrated that IL-1 $\beta(10 \mathrm{ng} / \mathrm{ml})$ inhibited acid secretion stimulated by histamine in a timedependent manner in isolated rabbit parietal cells.

Effect of IL-1 $\beta$ on $\mathrm{H}^{+} / \mathrm{K}^{+}$ATPase a subunit mRNA expression in isolated rabbit parietal cells. As demonstrated in Fig. 6, the mRNA expression of $\mathrm{H}^{+} / \mathrm{K}^{+}$ATPase $\alpha$ subunit in isolated rabbit parietal cells was downregulated by 11 and $29 \%$ following treat-

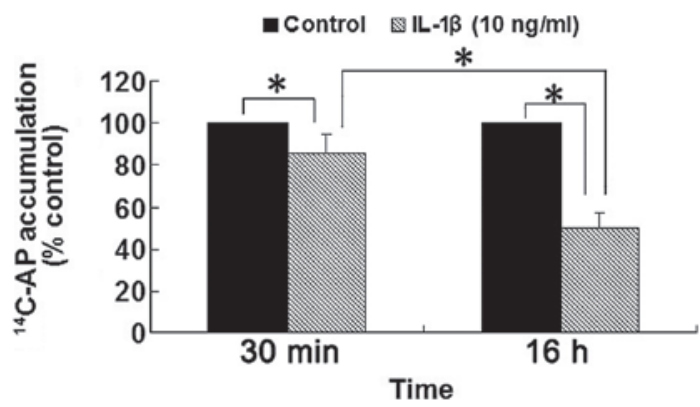

Figure 5. Inhibitory effect of IL-1 $\beta$ on acid secretion induced by histamine in isolated rabbit parietal cells. Isolated parietal cells were pre-incubated with IL-1 $\beta(10 \mathrm{ng} / \mathrm{ml})$ for $30 \mathrm{~min}$ or $16 \mathrm{~h}$ prior to stimulation by histamine $\left(10^{-4} \mathrm{~mol} / \mathrm{l}\right)$ for $30 \mathrm{~min}$. Level of acid secretion was reflected by ${ }^{14} \mathrm{C}$-aminopyrine $\left({ }^{14} \mathrm{C}-\mathrm{AP}\right)$ accumulation and the acid secretion of the control group is expressed as $100 \%$. Results are expressed as a percentage of the basal control. Data are expressed as the means $\pm S D(n=6)$. "P<0.05.

ment with IL-1 $\beta(10 \mathrm{ng} / \mathrm{ml})$ for $30 \mathrm{~min}$ and $16 \mathrm{~h}$, respectively, compared with the control group (all $\mathrm{P}<0.05$ ). Compared with the group treated with IL-1 $\beta(10 \mathrm{ng} / \mathrm{ml})$ for $30 \mathrm{~min}$, the mRNA expression of the $\mathrm{H}^{+} / \mathrm{K}^{+}$ATPase $\alpha$ subunit was significantly decreased in the group treated with IL-1 $\beta(10 \mathrm{ng} / \mathrm{ml})$ for $16 \mathrm{~h}$. These results indicated that IL-1 $\beta(10 \mathrm{ng} / \mathrm{ml})$ downregulated the mRNA expression of $\mathrm{H}^{+} / \mathrm{K}^{+}$ATPase $\alpha$ subunit in a timedependent manner in isolated rabbit parietal cells.

\section{Discussion}

Previous studies have demonstrated that human gastric mucosa expresses COX-2 protein at low levels; however, the expression of COX-2 is induced by $H$. pylori-associated premalignant and malignant gastric lesions and correlates with the depth of 

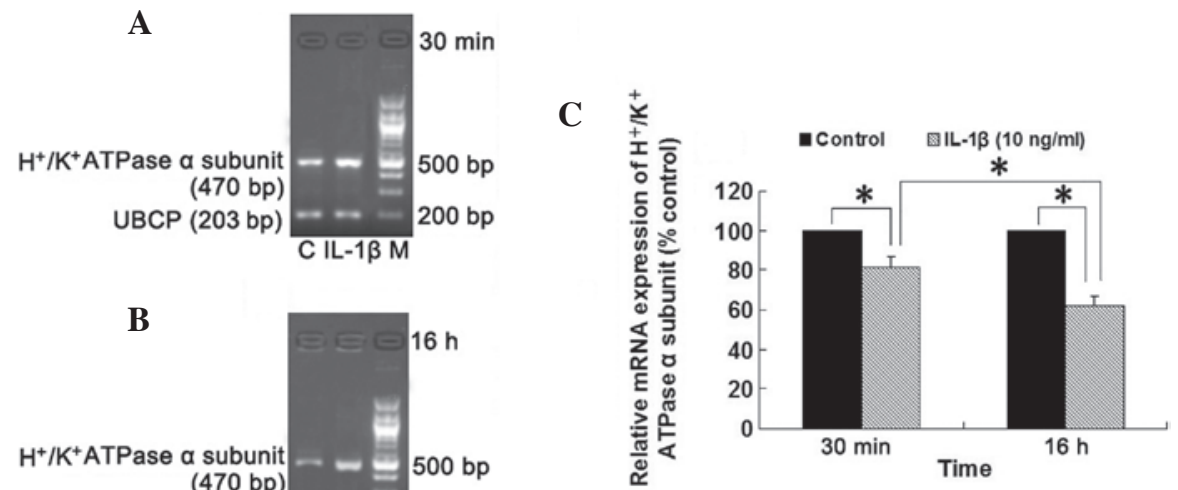

Figure 6. IL-1 $\beta$ downregulated $\mathrm{H}^{+} / \mathrm{K}^{+} \mathrm{ATPase} \alpha$ subunit mRNA expression in isolated rabbit parietal cells. Isolated parietal cells were incubated with IL-1 $\beta$ (10 ng/ml) for (A) $30 \mathrm{~min}$ or (B) $16 \mathrm{~h}$. C, control; IL-1 $\beta$, IL-1 $\beta$ (10 ng/ml) group; M, marker. (C) The level of mRNA expression was determined by RT-PCR. The mRNA expression of the control group is expressed as $100 \%$. Results are expressed as percentage of the control. Data are expressed as the means \pm SD $(n=6) .{ }^{*} \mathrm{P}<0.05$.

mucosal invasion, lymphatic invasion and metastasis in human gastric carcinoma (11-13). Specific and non-specific inhibitors of COX-2 suppressed proliferation of cell lines that expressed high levels of COX-2. However, these inhibitors exerted minimal effects on proliferation of the cell lines expressing lower levels of COX-2 (14). In addition, COX-2 inhibitors suppressed growth of gastric cancer xenografts by induction of apoptosis and suppression of neoplastic cell replication (15). These results indicate that COX-2 is important for the development of gastric cancer. The present study identified the basal COX-2 expression in the transformed human gastric cancer cell line (AGS) and human gastric epithelial cell line (GES-1) using RT-PCR.

Although the mechanism of COX-2 regulation of cancer development remains unclear, existing data indicate that COX-2 expression is associated with stimulation of cellular proliferation and resistance to apoptosis. Previously, COX-2 inhibitor treatment was observed to induce apoptosis, suppress cellular proliferation, downregulate $\mathrm{Bcl}-2$ expression and suppress the growth of H-ras-transformed cells (16-18). In addition, overexpression of COX-2 may induce expression of epidermal growth factor receptor and metalloproteinase and decrease expression of E-cadherin and transforming growth factor- $\beta$ receptor $(15,19)$. These alterations are correlated with enhanced tumorigenic potential and increased tumor invasiveness.

COX-2 expression is associated with intensive infiltration of inflammatory cells in $H$. pylori-infected gastric mucosa where substantial amounts of cytokines are induced, including IL-1 $\beta(20,21)$. A previous study by Zhang et al demonstrated that $H$. pylori isogenic mutants specifically lacking picA or picB, molecules responsible for cytokine production in gastric cells, are less effective in upregulation of COX-2 mRNA expression (22). These results indicate that picA and picB may contribute to increased COX-2 expression and stimulation of cytokine production. In the present study, the effect of exogenous IL-1 $\beta$ on COX-2 expression of gastric epithelial cells was analyzed. The results demonstrated that IL- $1 \beta$ induced the expression of COX- 2 mRNA and protein in GES-1 and AGS cell lines. COX-2 expression induced by IL-1 $\beta$ may be mediated by activation of multiple intracellular signaling pathways, including p44/42 and p38 MAPK, JNK and $N F-\kappa B(23,24)$. The results of the present study revealed that IL-1 $\beta$ enhanced cellular proliferation and attenuated $H$. pylori-induced apoptosis in GES-1 and AGS cell lines, consistent with the observation that IL-1 $\beta$ induced expression of COX-2. Therefore, we conclude that $H$. pylori-associated IL-1 $\beta$ may stimulate cellular proliferation, inhibit $H$. pyloriinduced apoptosis and mediate gastric carcinogenesis through upregulation of COX-2 expression. Additional mechanisms by which IL-1 $\beta$ affects carcinogenesis may include IL-1 $\beta$ induction of angiogenin mRNA and protein expression. Angiogenin is a proangiogenic molecule associated with neovascularization of cancer tissue. IL-1 $\beta$ may also induce carcinogenesis by stimulation of metalloproteinases, thought to be important mediators of metastasis $(25,26)$. Maihöfner et al revealed that expression of COX-2 was consistent with expression of IL-1 $\beta$ in human colorectal cancer tissue, however, the association between COX-2 and IL-1 $\beta$ in human gastric cancer tissue requires additional investigation (27).

In humans, $H$. pylori infection may cause acute epidemic gastritis associated with hypochlorhydria. In certain individuals, chronic $H$. pylori infection causes body-predominant gastritis and profound suppression of gastric acid secretion that is partially reversible with eradication therapy (28-30). The degree of acid suppression depends on the distribution of $H$. pylori infection, scores for activity and inflammation of gastritis in the body, the number of $H$. pylori and the grade of colonization (31). In the present study, ${ }^{14} \mathrm{C}$-AP accumulation was performed to determine the effects of exogenous IL- $1 \beta$ on acid secretion in isolated parietal cells from rabbits. The results demonstrated that IL-1 $\beta$ exposure for $30 \mathrm{~min}$ or $16 \mathrm{~h}$ inhibited histamine-stimulated acid secretion, accompanied by downregulation of $\mathrm{H}^{+} / \mathrm{K}^{+}$ATPase mRNA expression. The inhibitory potency of IL- $1 \beta$ was time-dependent, as preincubation of parietal cells with IL-1 $\beta$ for longer time intervals resulted in increased inhibition of ${ }^{14} \mathrm{C}$-AP accumulation and downregulation of $\mathrm{H}^{+} / \mathrm{K}^{+}$ATPase mRNA expression. Since specific $\mathrm{H}^{+} / \mathrm{K}^{+}$ATPase in parietal cell is the key mediator of the final stages of gastric acid secretion, a decrease in the level of $\mathrm{H}^{+} / \mathrm{K}^{+}$ATPase is hypothesized to lead to a reduc- 
tion of acid secretion (32). The present results indicate that IL-1 $\beta$ may inhibit gastric acid secretion by downregulating expression of $\mathrm{H}^{+} / \mathrm{K}^{+}$ATPase. However, the possibility that IL-1 $\beta$ performs antisecretory functions in parietal cells by blocking $\mathrm{H}^{+} / \mathrm{K}^{+}$ATPase activity cannot be ruled out at present. Accumulating evidence indicates that the inhibitory action of IL-1 $\beta$ is mediated by multiple intracellular signaling pathways, including pertussis toxin and tyrosine kinase-dependent and independent pathways $(33,34)$.

Additional in vivo studies are consistent with the present in vitro results. In Mongolian gerbils inoculated orally with H. pylori for 6 and 12 weeks, serum gastrin levels were increased and gastric acid output was decreased. These alterations correlated with elevation of IL- $1 \beta$ mRNA levels in gastric mucosa; however, gastric acid output and serum gastrin level returned to control levels following recombinant human IL-1 receptor antagonist (rhIL-1 ra) injection. In H.pylori-associated enlarged fold gastritis, increased IL- $1 \beta$ release from gastric body mucosa was correlated with decreased basal and tetragastrinstimulated acid output, whereas IL-1 $\beta$ release was significantly decreased with concomitant increase in gastric acid secretion following eradication of $H$. pylori. In patients infected with $H$. pylori, a significant correlation was observed between IL-1 $\beta$ mRNA expression in gastric fundic gland mucosa and gastric juice $\mathrm{pH}$. Significant decreases in the amount of IL-1 $\beta$ mRNA, gastric juice $\mathrm{pH}$ and serum gastrin levels were observed in patients with eradication of $H$. pylori, whereas no significant changes were observed in patients without eradication (35). These results indicate that $H$. pylori infection induces IL-1 $\beta$ expression and suppresses acid secretion.

In addition to the direct effects on parietal cells, the mechanisms by which the inhibitory effects of IL-1 $\beta$ on acid secretion are mediated in vivo are: i) IL-1 $\beta$ induces apoptosis in enterochromaffin-like cells (ECL cells) or inhibits gastric histamine secretion and synthesis from ECL cells, leading to the reduction in acid secretion stimulated by histamine $(36,37)$. ii) IL-1 $\beta$ mediates increased prostaglandin E2 $\left(\mathrm{PGE}_{2}\right)$ production via the overexpression of $\mathrm{COX}-2 . \mathrm{PGE}_{2}$ functions as a potent inhibitor of gastric acid secretion by directly retarding the secretory function of parietal cells or reducing histamine release from ECL cells. Moreover, $\mathrm{PGE}_{2}$ stimulates bicarbonate secretion from gastric epithelial cells, which may contribute to a decrease in gastric acidity (38-40). A previous study in $H$. pylori-infected mice demonstrated that increased $\mathrm{PGE}_{2}$ produced by overexpression of COX-2 stimulated cytokines (IL-1 $\beta$ ) induced by $H$. pylori infection, demonstrating the importance of $\mathrm{PGE}_{2}$ in gastric acid hyposecretion by $H$. pylori infection (41).

One of the mechanisms involved in the development of gastric cancer by $H$. pylori infection is associated with long-term acid hyposecretion. Patients with hyposecretion are exposed to hypergastrinemia, bacterial toxins, $\mathrm{N}$-nitroso compounds and products of inflammation, including reactive oxygen radicals and nitrogen oxygen species, all well-known mutagens or carcinogens $(5,7)$. In hosts with low basal secretory capacity and high IL-1 $\beta$ phenotypes, $H$. pylori is prone to colonization of a wider niche involving the acid secretory corpus region, resulting in higher levels of IL- $1 \beta$ production, resulting in additional inhibition of acid secretion, a more aggressive body gastritis and acceleration of gastric cancer development. A previous study in Mongolian gerbils with low basal acid output and genetic predisposition demonstrated that gerbils developed corpus atrophy, intestinal metaplasia and were particularly prone to developing gastric cancer when chronically colonized by $H$. pylori infection (42). These observations are consistent with a phenotype identified in human individuals associated with increased risk of gastric cancer with high IL-1 $\beta$ phenotypes.

In conclusion, the results from the present study suggest that IL-1 $\beta$ may be a key mediator in $H$. pylori-induced gastric carcinogenesis and a prime candidate as a host genetic factor that may alter the risk of gastric cancer. The present study demonstrates that IL- $1 \beta$ induced by $H$. pylori infection is associated with the 2 mechanisms involved in gastric carcinogenesis: i) IL-1 $\beta$ may promote cellular proliferation, inhibit $H$. pylori-induced apoptosis by upregulating COX-2 expression and lead to the disturbance of gastric epithelial cell growth and ii) IL-1 $\beta$ may inhibit acid secretion from parietal cells by downregulating $\mathrm{H}^{+} / \mathrm{K}^{+}$ATPase expression.

\section{Acknowledgements}

The present study was supported and funded by the National Natural Science Foundation of China (NSFC-30270600).

\section{References}

1. Momtaz H, Souod N, Dabiri H and Sarshar M: Study of Helicobacter pylori genotype status in saliva, dental plaques, stool and gastric biopsy samples. World J Gastroenterol 18: 2105-2111, 2012.

2. Graham DY and Yamaoka Y: Disease-specific Helicobacter pylori virulence factors: the unfulfilled promise. Helicobacter 5: 3-9, 2000.

3. Hitzler I, Sayi A, Kohler E, et al: Caspase-1 has both proinflammatory and regulatory properties in Helicobacter infections, which are differentially mediated by its substrates IL- $1 \beta$ and IL-18. J Immunol 188: 3594-3602, 2012.

4. Albaker WI: Helicobacter pylori infection and its relationship to metabolic syndrome: is it a myth or fact? Saudi J Gastroenterol 17: 165-169, 2011.

5. El-Omar EM, Carrington M, Chow WH, et al: Interleukin-1 polymorphisms associated with increased risk of gastric cancer. Nature 404: 398-402, 2000.

6. Tan IB, Ng I, Tai WM and Tan P: Understanding the genetic basis of gastric cancer: recent advances. Expert Rev Gastroenterol Hepatol 6: 335-341, 2012.

7. Cai $C$ and Zhu $X$ : The Wnt/ $\beta$-catenin pathway regulates selfrenewal of cancer stem-like cells in human gastric cancer. Mol Med Report 5: 1191-1196, 2012.

8. Wang XC, Li Y, Fan LQ, et al: Integrase interactor 1 regulates proliferation, apoptosis and invasion in gastric cancer cells. Chin Med J (Engl) 125: 527-532, 2012.

9. Tu SP, Quante M, Bhagat G, et al: IFN- $\gamma$ inhibits gastric carcinogenesis by inducing epithelial cell autophagy and T-cell apoptosis. Cancer Res 71: 4247-4259, 2011.

10. Li XB, Qian JM, Chen YJ and Chen YF: Effect of lansoprazole on histamine-induced acid secretion in isolated rabbit parietal cells. Chin J Dig Dis 3: 47-50, 2002.

11. Sung JJ, Leung WK, Go MY, et al: Cyclooxygenase-2 expression in Helicobacter pylori-associated premalignant and malignant gastric lesions. Am J Pathol 157: 729-735, 2000.

12. Pero R, Peluso S, Angrisano T, et al: Chromatin and DNA methylation dynamics of Helicobacter pylori-induced COX-2 activation. Int J Med Microbiol 301: 140-149, 2011.

13. Ohno R, Yoshinaga K, Fujita T, et al: Depth of invasion parallels increased cyclooxygenase-2 levels in patients with gastric carcinoma. Cancer 91: 1876-1881, 2001.

14. Zhang Y, Xu X and He P: Tubeimoside-1 inhibits proliferation and induces apoptosis by increasing the $\mathrm{Bax}$ to $\mathrm{Bcl}-2$ ratio and decreasing COX-2 expression in lung cancer A549 cells. Mol Med Report 4: 25-29, 2011. 
15. Gou HF, Chen XC, Zhu J, et al: Expressions of COX-2 and VEGF-C in gastric cancer: correlations with lymphangiogenesis and prognostic implications. J Exp Clin Cancer Res 30: 14, 2011.

16. Huang DS, Shen KZ, Wei JF, et al: Specific COX-2 inhibitor NS398 induces apoptosis in human liver cancer cell line HepG2 through BCL-2. World J Gastroenterol 11: 204-207, 2005.

17. Nandi J, Das PK, Zinkievich JM, et al: Cyclo-oxygenase-1 inhibition increases acid secretion by modulating $\mathrm{H}^{+}, \mathrm{K}^{+}$-ATPase expression and activation in rabbit parietal cells. Clin Exp Pharmacol Physiol 36: 127-134, 2009.

18. $\mathrm{Na} \mathrm{HK}$, Inoue $\mathrm{H}$ and Surh YJ: ET-18-O- $\mathrm{CH}_{3}$-induced apoptosis is causally linked to COX-2 upregulation in $\mathrm{H}$-ras transformed human breast epithelial cells. FEBS Lett 579: 6279-6287, 2005.

19. Timotheadou E, Skarlos DV, Samantas E, et al: Evaluation of the prognostic role of a panel of biomarkers in stage IB-IIIA non-small cell lung cancer patients. Anticancer Res 27: 4481-4489, 2007.

20. Seo JH, Seo JY, Chung HY and Kim H: Effect of pertussis toxin and herbimycin A on proteinase-activated receptor 2-mediated cyclooxygenase 2 expression in Helicobacter pylori-infected gastric epithelial AGS cells. Yonsei Med J 52: 522-526, 2011.

21. Tatsuguchi A, Sakamoto C, Wada K, et al: Localisation of cyclooxygenase 1 and cyclooxygenase 2 in Helicobacter pylori related gastritis and gastric ulcer tissues in humans. Gut 46: 782-789, 2000.

22. Zhang $\mathrm{X}$, Zhong $\mathrm{R}$, Zhang $\mathrm{Z}$, et al: Interaction of cyclooxygenase-2 promoter polymorphisms with Helicobacter pylori infection and risk of gastric cancer. Mol Carcinog 50: 876-883, 2011.

23. Liu W, Reinmuth N, Stoeltzing O, et al: Cyclooxygenase-2 is up-regulated by interleukin-1 beta in human colorectal cancer cells via multiple signaling pathways. Cancer Res 63: 3632-3636, 2003.

24. Catley MC, Chivers JE, Cambridge LM, et al: IL-1beta-dependent activation of NF-kappaB mediates PGE2 release via the expression of cyclooxygenase- 2 and microsomal prostaglandin $\mathrm{E}$ synthase. FEBS Lett 547: 75-79, 2003.

25. Etoh T, Shibuta K, Barnard GF, et al: Angiogenin expression in human colorectal cancer: the role of focal macrophage infiltration. Clin Cancer Res 6: 3545-3551, 2000.

26. Paduch R, Kandefer-Szerszeń M, Szuster-Ciesielska A and Plewka K: Transforming growth factor-betal modulates metalloproteinase-2 and -9, nitric oxide, RhoA and alpha-smooth muscle actin expression in colon adenocarcinoma cells. Cell Biol Int 34: 213-223, 2010.

27. Maihöfner C, Charalambous MP, Bhambra U, et al: Expression of cyclooxygenase-2 parallels expression of interleukin-1beta, interleukin-6 and NF-kappaB in human colorectal cancer. Carcinogenesis 24: 665-671, 2003.

28. Sugimoto M, Furuta T, Shirai N, et al: Evidence that the degree and duration of acid suppression are related to Helicobacter pylori eradication by triple therapy. Helicobacter 12: 317-323, 2007.
29. Oridate N, Takeda H, Yamamoto J, et al: Helicobacter pylori seropositivity predicts outcomes of acid suppression therapy for laryngopharyngeal reflux symptoms. Laryngoscope 116: 547-553, 2006.

30. Zhu H, Hart CA, Sales D and Roberts NB: Bacterial killing in gastric juice - effect of $\mathrm{pH}$ and pepsin on Escherichia coli and Helicobacter pylori. J Med Microbiol 55: 1265-1270, 2006.

31. Takashima M, Furuta T, Hanai H, et al: Effects of Helicobacter pylori infection on gastric acid secretion and serum gastrin levels in Mongolian gerbils. Gut 48: 765-773, 2001.

32. Nguyen NV, Gleeson PA, Courtois-Coutry N, et al: Gastric parietal cell acid secretion in mice can be regulated independently of H/K ATPase endocytosis. Gastroenterology 127: 145-154, 2004.

33. Wei XH, Yang T, Wu Q, et al: Peri-sciatic administration of recombinant rat IL-1 $\beta$ induces mechanical allodynia by activation of src-family kinases in spinal microglia in rats. Exp Neurol 234: 389-397, 2012.

34. Shibata Y, Kasai H, Shimada M, et al: IL-1 $\beta$ stimulates IL-8 production, including prostaglandin E2 receptor EP4-triggered pathways, in synoviocyte MH7A cells. Mol Med Report 2: 359-363, 2009.

35. Sugimoto M, Furuta T and Yamaoka Y: Influence of inflammatory cytokine polymorphisms on eradication rates of Helicobacter pylori. J Gastroenterol Hepatol 24: 1725-1732, 2009.

36. Kidd M, Gustafsson BI, Drozdov I and Modlin IM: IL1beta- and LPS-induced serotonin secretion is increased in EC cells derived from Crohn's disease. Neurogastroenterol Motil 21: 439-450, 2009.

37. Beales IL: Gastrin and interleukin-lbeta stimulate growth factor secretion from cultured rabbit gastric parietal cells. Life Sci 75: 2983-2995, 2004

38. Shimamoto C, Nakanishi Y, Katsu K, et al: Prostaglandin E2 release in gastric antral mucosa of guinea-pigs: basal PGE2 release by cyclo-oxygenase 2 and ACh-stimulated PGE2 release by cyclo-oxygenase 1. Exp Physiol 91: 1015-1024, 2006.

39. Zinkievich JM, George S, Jha S, et al: Gastric acid is the key modulator in the pathogenesis of non-steroidal anti-inflammatory drug-induced ulceration in rats. Clin Exp Pharmacol Physiol 37: 654-661, 2010

40. Sekiguchi F, Ohi A, Maeda Y, et al: Delayed production of arachidonic acid contributes to the delay of proteinase-activated receptor-1 (PAR1)-triggered prostaglandin E2 release in rat gastric epithelial RGM1 cells. J Cell Biochem 112: 909-915, 2011.

41. Xiao F, Furuta T, Takashima M, et al: Effects of cyclooxygenase-2 inhibitor on gastric acid secretion in Helicobacter pylori-infected C57BL/6 mice. Scand J Gastroenterol 36: 577-583, 2001.

42. Pal J, Sanal MG and Gopal GJ: Vitamin-C as anti-Helicobacter pylori agent: More prophylactic than curative - Critical review. Indian J Pharmacol 43: 624-627, 2011. 